\title{
Seismic stratigraphy and glacial cycles in the inland passages of the Magallanes Region of Chile, southernmost South America
}

\author{
Rodrigo Fernández ${ }^{\mathrm{a}, *}$, Sean Gulick ${ }^{\mathrm{a}}$, Cristian Rodrigo ${ }^{\mathrm{b}}$, Eugene Domack ${ }^{\mathrm{c}}$, Amy Leventer ${ }^{\mathrm{d}}$ \\ a University of Texas Institute for Geophysics, 10100 Burnet Road (R2200), Building 196, Austin, TX, United States \\ b Universidad Andres Bello, Calle Quillota 980, Viña del Mar, Región de Valparaíso, Chile \\ c University of South Florida, 4202 East Fowler Avenue, Tampa, Florida, United States \\ ${ }^{d}$ Colgate University, 13 Oak Drive, Hamilton, New York, United States
}

\section{A R T I C L E I N F O}

\section{Article history:}

Received 16 August 2016

Received in revised form 4 February 2017

Accepted 9 February 2017

Available online 12 February 2017

\begin{abstract}
A B S T R A C T
We present results of a marine geophysical survey that imaged submarine sedimentary and geomorphic features of the main inland channels of the Magallanes Region of Chile, in southernmost South America. This region holds a remarkable terrestrial and marine record of glacial variations in the closest landmass to Antarctica. We report evidence for grounded ice along the main channels associated with two ice lobes that flowed from Cordillera Darwin, part of the Austral Andes, into Central Estrecho de Magallanes and Seno Almirantazgo. Multibeam data show drumlins and glacial lineations in Whiteside Channel the northern continuation of Seno Almirantazgo, and iceberg plough marks in Central Estrecho de Magallanes. Multichannel seismic data show a complex array of seismic facies, interpreted as representing two main types of sedimentary units: glacimarine sediments, corresponding to glacial periods, and pelagic sediments, corresponding to interglacial periods. We find that there are two interglacial-glacial cycles represented in this marine sedimentary record. Chronologically: 1) the youngest glacial unit corresponds to the last regional glaciation $(\sim 31-18 \mathrm{ka}) ; 2)$ these passageways deglaciated with the retreat from regional glacial limit ' $\mathrm{D}$ ' ( 17-18 ka), and 3) there is no marine sedimentary or morphological evidence that the Magallanes glaciers readvanced into the main passageways during the Antarctic Cold Reversal ( $\sim 14-$ $13 \mathrm{ka}$ ). These findings suggest that final deglaciation of southernmost South America was driven by the atmospheric and ocean warming that started $\sim 18 \mathrm{ka}$ as recorded in Antarctic ice core records and sea surface temperature proxies offshore the Magallanes Region.
\end{abstract}

(c) 2017 Elsevier B.V. All rights reserved.

\section{Introduction}

Ice fields, ice caps, and mountain glaciers in southern Patagonia constitute the largest masses of ice in the southern hemisphere outside Antarctica. Models suggest that present day Patagonian ice bodies represent $<20 \%$ of their Last Glacial Maximum (LGM) extent, which constitute a mass loss equivalent to $\sim 1.2 \mathrm{~m}$ of global sea level change (Hulton et al., 2002). The Magallanes Region of Chile comprises most of the Austral Andes mountains and fjords of southern Patagonia between $49^{\circ}-56^{\circ} \mathrm{S}$, including western Tierra del Fuego Island and a myriad of other smaller islands. The Estrecho de Magallanes $\left(\sim 53^{\circ} \mathrm{S}\right.$; also referred as "Strait of Magellan"), located in the Magallanes Region of Chile, is an inland passage that crosses the southern Patagonian Andes and connects the Pacific and Atlantic oceans (Fig. 1). During the LGM, ice lobes extended over the Estrecho de Magallanes up to $200 \mathrm{~km}$ from the axis of Patagonian Andes and Darwin cordilleras (Coronato et al., 1999).

\footnotetext{
* Corresponding auhor.

E-mail address: r.f@ig.utexas.edu (R. Fernández).
}

Individual ice bodies such as Bahía Inútil and Central Estrecho de Magallanes lobes, reached widths of up to $\sim 30 \mathrm{~km}$ (Fig. 1; Coronato et al., 1999). The center of the ice sheet was $>1 \mathrm{~km}$ thick and located along the axis of the Cordillera Andes (Hulton et al., 2002). Streamlined landforms, partially attributed to the Late Pleistocene Patagonian Ice Sheet (LPPIS) (Bentley et al., 2005), including drumlins and flutes flanking the Central Estrecho de Magallanes, indicate that glacial ice flowed radially near the border of the LPPIS on the nearly flat coastal areas of the Magallanes Region (Bentley et al., 2005).

Marine geophysical and geological data is very sparse in the region, especially near the LPPIS influenced Estrecho de Magallanes. The most extensive previous seismic survey (Bartole et al., 2008) obtained relatively deep penetrating and low resolution sections along the Estrecho de Magallanes and the northernmost part of Whiteside Channel (Fig. 1). Their data show a regional angular unconformity overlain by late Neogene (?) strata of varying thickness and complex internal architecture, and provide indications of possible glacial influence. However, the low resolution of the seismic images prevents an unambiguous identification of seismic facies and the establishment of a reliable seismic-stratigraphy framework for the area. 


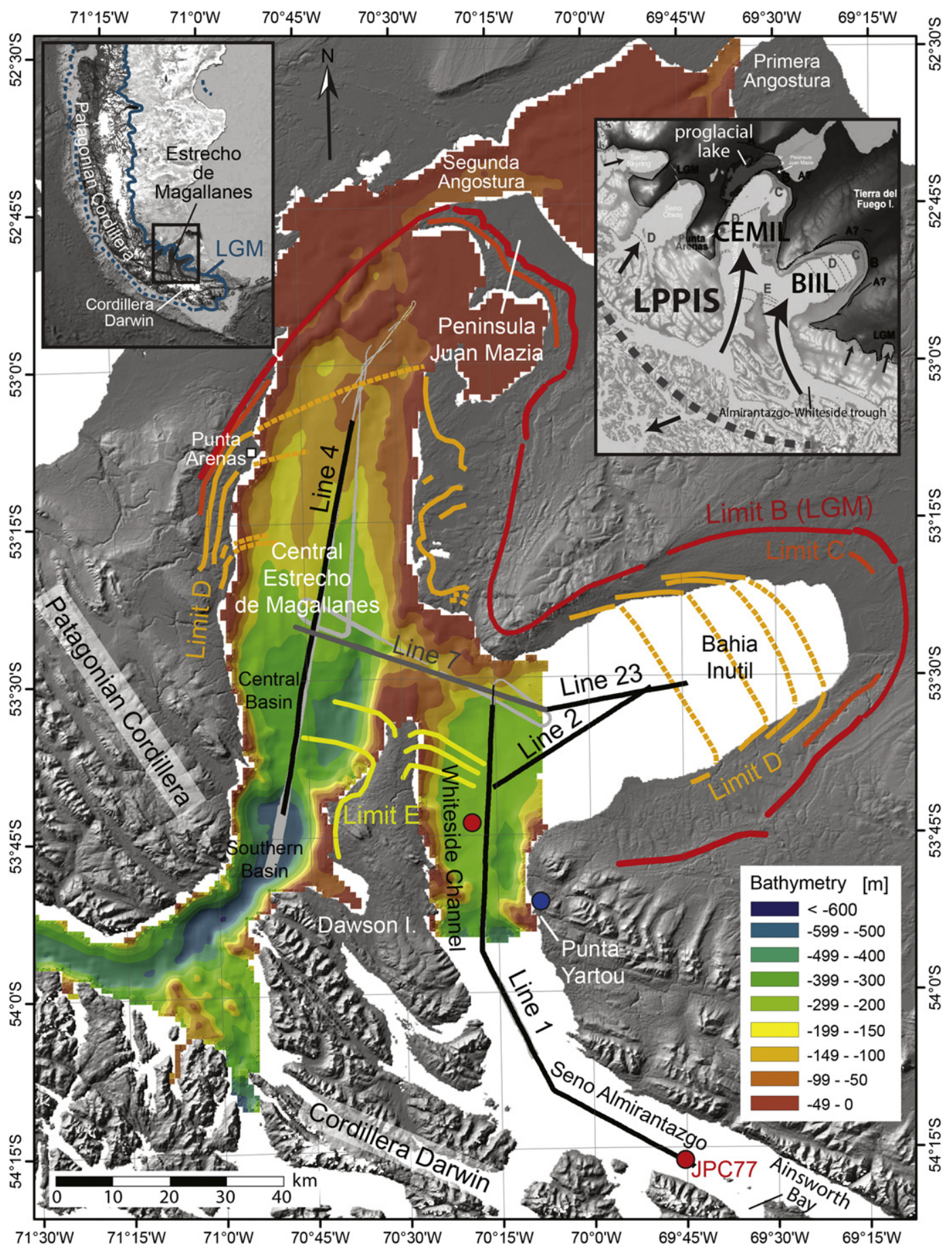

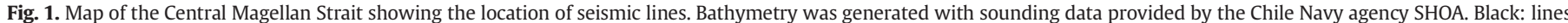

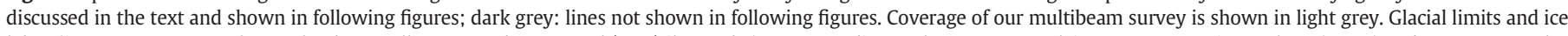

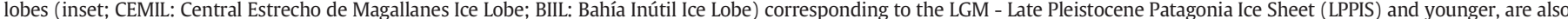

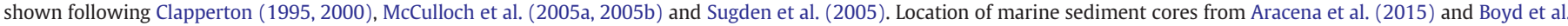
(2008) are indicated by red circles. Peat bog core in Punta Yartou (Mansilla et al., 2016) is indicated by a blue circle.

Less extensive but more detailed studies have documented glacial sediments in some marine inlets near Estrecho de Magallanes, east of Cordillera Darwin (Fig. 1). In Ainsworth Bay (Fig. 1), a relatively proximal basin fed mostly with sediments from Marinelli Glacier, Boyd et al. (2008) and Fernandez et al. (2011) described sediment cores and seismic facies showing the existence of $>100 \mathrm{~m}$ of glacimarine and pelagic sediments that accumulated since the deglaciation of the bay about 12.5 ka. Farther north, in Bahía Inútil (Fig. 1), Anderson and Archer (1999), cored a diamictite overlain by pelagic sediment thought to represent very low rates of postglacial accumulation. Nearby Whiteside Channel, Aracena et al. (2015) obtained a $22 \mathrm{~m}$ long core and documented glacial proximal and pelagic sediments evidencing salinity and productivity changes during the Holocene, however this core did not provide datable material for the deepest pebbly facies interpreted as being glacial proximal and thus the age of glacial retreat from this submerged area is still unknown. These marine studies demonstrate strong glacial influence but document only postglacial and mostly Holocene sedimentary sequences and lack of an appropriate 
seismic stratigraphic framework which prevents the contextualization of their stratigraphic and paleoenvironmental findings.

Terrestrial studies near Estrecho de Magallanes (east of the Andes), have shown that the waning of the LPPIS and final deglaciation of the Magallanes Region was a complex process, and included one or more late glacial (latest Pleistocene) advances before the final retreat of the ice into the fjords and higher areas of the Patagonian Andes and Cordillera Darwin (Fig. 1; Clapperton, 1995; McCulloch and Bentley, 1998; McCulloch et al., 2000, 2005a, 2005b; Clapperton, 2000; Bentley et al., 2005; Sugden et al., 2005; Kilian et al., 2007a). The evidence comes from a series of glacial landforms (e.g., terminal and retreat moraines), boulder fields and outwash channels on both sides of the Estrecho de Magallanes (e.g. Clapperton, 1995, 2000; McCulloch et al., 2005a; Sugden et al., 2005). A series of five moraine systems outcropping in coastal areas of the Estrecho de Magallanes and Dawson Island, are referred as glacial limits 'A' to 'E' from outer to inner location with respect to the Patagonian Andes (Fig. 1; Clapperton, 1995, 2000; McCulloch et al., 2005a). The LGM is represented by limit 'B' and that glaciers began to advance over the central part of Estrecho de Magallanes sometime after 31,250 cal yrs BP, culminating at c. 25, 200-23,100 cal yrs BP (McCulloch et al., 2005a; Kaplan et al., 2008; Fig. 1). Glacial limit 'C' (Fig. 1) would represent a slightly less extensive advance from which ice retreated sometime before c. 21, 700-20,400 cal yrs BP (McCulloch et al., 2005a; Kaplan et al., 2008; Fig. 1). Glacial limit 'D' interpreted as a late glacial advance subsequent to the glacial retreat from limit ' $C$ ', is associated with a series of recessional moraines with abundant granitic boulders that crop out in Bahía Inútil and both shores of the Central Estrecho de Magallanes. These boulders represent the last evidence of glacial activity in these areas ( 17-18 ka; McCulloch et al., 2005a, 2005b; Kaplan et al., 2008).

It has been proposed that the glacial advance related to limit ' $E$ ' was coincident with the Antarctic Cold Reversal (ACR; McCulloch et al., 2005a), a cold phase that interrupted the late Pleistocene warming trend as manifested in Antarctic ice core records ( 13-14.8 cal yrs BP; Blunier and Brook, 2001; EPICA Community Members, 2004). There is evidence of ACR coeval glacial advances farther north in the Torres del Paine National Park (e.g. García et al., 2012), and due to its closeness, the climate of the Magallanes Region is influenced by major Antarctic circulation systems such as the Antarctic Circumpolar Current and the Polar Cell (e.g. Lamy et al., 2010; Garreaud et al., 2013). However, evidence of a glacial event during the ACR in the Estrecho de Magallanes area is ambiguous and conflicts with recent findings from Seno Almirantazgo and the Marinelli Glacier area. Results from Boyd et al. (2008) indicate that ice had retreated from most of Seno Almirantazgo by $\sim 15.5 \mathrm{ka}$, while Hall et al. (2013) shows that ice had significantly thinned in these areas by $\sim 16 \mathrm{ka}$. These studies found no evidence of a glacial readvance on Seno Almirantazgo after $16 \mathrm{ka}$. However, the available evidence is still inconclusive since there have been no studies of the late Pleistocene marine sedimentary record nor of the sea floor geomorphology in this marine inlet.

Ample geological evidence exists for older glaciations in central Patagonia and Tierra del Fuego Island (Rabassa et al., 2000, 2005; Wenzens, 2006; Lagabrielle et al., 2010) dating back to the Late Miocene and early Pleistocene respectively. In Tierra del Fuego Island, extensive glacial drifts include glacial, glacifluvial and glacilacustrine deposits that are thought to be derived from ice lobes that followed paths similar to the LPPIS (Rabassa et al., 2000). Whether or not there is submarine evidence of these older glaciations in the inlets of Magallanes is unknown.

Here we present the results of the first high-resolution seismic survey aimed to image the main paths of the Pleistocene ice lobes in the Estrecho de Magallanes area. We provide a seismic stratigraphic framework for the area to support the interpretation of currently available sedimentary and morphological data and guide future studies. A complex array of seismic facies and major seismic units are presented allowing us to propose that the main marine inlets of the Magallanes Region, Seno Almirantazgo, Whiteside Channel and the Central Estrecho de Magallanes, possess a sedimentary record of at least two complete glacial-interglacial cycles. We also present multibeam bathymetry data supporting the existence of grounded ice in the deepest parts of Seno Almirantazgo, and evidence of iceberg scours in Estrecho de Magallanes. The combined seismic and morphological evidence collected as part of this research do not support the existence of grounded ice associated with glacial limit 'E' nor a glacial readvance into the lowlands and thus support recent findings pointing to a rapid deglaciation of Magallanes main marine pathways after the last glacial advance at $>17 \mathrm{ka}$, and thus question the idea of an extensive response of Patagonian Glaciers to the ACR.

\section{Methods}

Seismic and bathymetry data were collected as part of the 2012 RVIB Nathaniel B. Palmer (NBP) seismic sea trial cruise NBP1208 along the Central Estrecho de Magallanes, Whiteside Channel, Seno Almirantazgo and Bahía Inútil in the Magallanes Region of Chile. Bathymetry and compressed high-intensity radar pulse (CHIRP) seismic data were collected using NBP hull mounted equipment coincident with multi-channel seismic (MCS) data. Bathymetry data was acquired using the NBP hullmounted Simrad EM120 multibeam sonar system, which consists of 120 beams with a $12 \mathrm{kHz}$ source. Data were processed post-cruise using Caris software including editing for artifacts and bad pings, and producing gridded 3D bathymetry for geomorphological analysis that were visualized using Fledermaus software. CHIRP data were acquired with the NBP Knudsen 3260 sub-bottom profiler ( $3.5 \mathrm{kHz}, 10 \mathrm{~kW}$ ), which produces full waveform data. Basic gain and band pass adjustments were done after the cruise using Focus seismic processing software for better visualization of the imaged sections. The Knudsen data is internally adjusted for depth using a p-wave velocity of $1500 \mathrm{~m} / \mathrm{s}$ and so this value is used to convert back to two-way travel time when comparing it with MCS data.

The MCS acquisition array consisted of dual $45 / 45 \mathrm{cu}$. in. GeneratorInjector (GI) air guns with a hot spare and a $100 \mathrm{~m}$ long gel-filled streamer ( $75 \mathrm{~m}$ active) with 24 channels with a spacing of $3.125 \mathrm{~m}$. The processing of the MCS data included prestack bandpass filtering and spherical divergence correction, deconvolution of the resulting signal to isolate the earth response (predictive, effective source wavelet and/or Hilbert transform deconvolution), trace balancing, normal moveout correction, stacking and dip moveout, and migration in the frequency-wavenumber domain. The interpretation of the seismic section focused on the finding of characteristic seismic facies and the geometric relationship between them.

\section{Results}

\subsection{Swath bathymetry}

Swath bathymetry mapping revealed several types of sea floor features in Seno Almirantazgo, White Side Channel and the southern Central Estrecho de Magallanes (Fig. 2). Restricted coverage and/or noisy data prevented the identification in other areas.

Elongated features occur parallel to the axis of the Seno Almirantazgo Sound and thus, follow the primary paleo-ice flow direction (Fig. 2). These features are $<5 \mathrm{~km}$ long and $4 \mathrm{~m}$ high and are present near Dawson Island. Features exhibit generally positive bathymetric relief but some seem to be bounded or shaped by elongated depressions (Fig. 2). They generally occur in shallow areas associated with thick sedimentary fillings as determined by the seismic data.

Directly south of the Dawson Island area there is a group of asymmetric features resembling drumlins that occur parallel to the previously described elongated features. These asymmetric features are $<40 \mathrm{~m}$ high and $1 \mathrm{~km}$ long and have a steep south-facing slope and a gentle north-facing slope. One group occurs in a low-relief area associated with acoustic basement promontories as seen in the seismic data. 


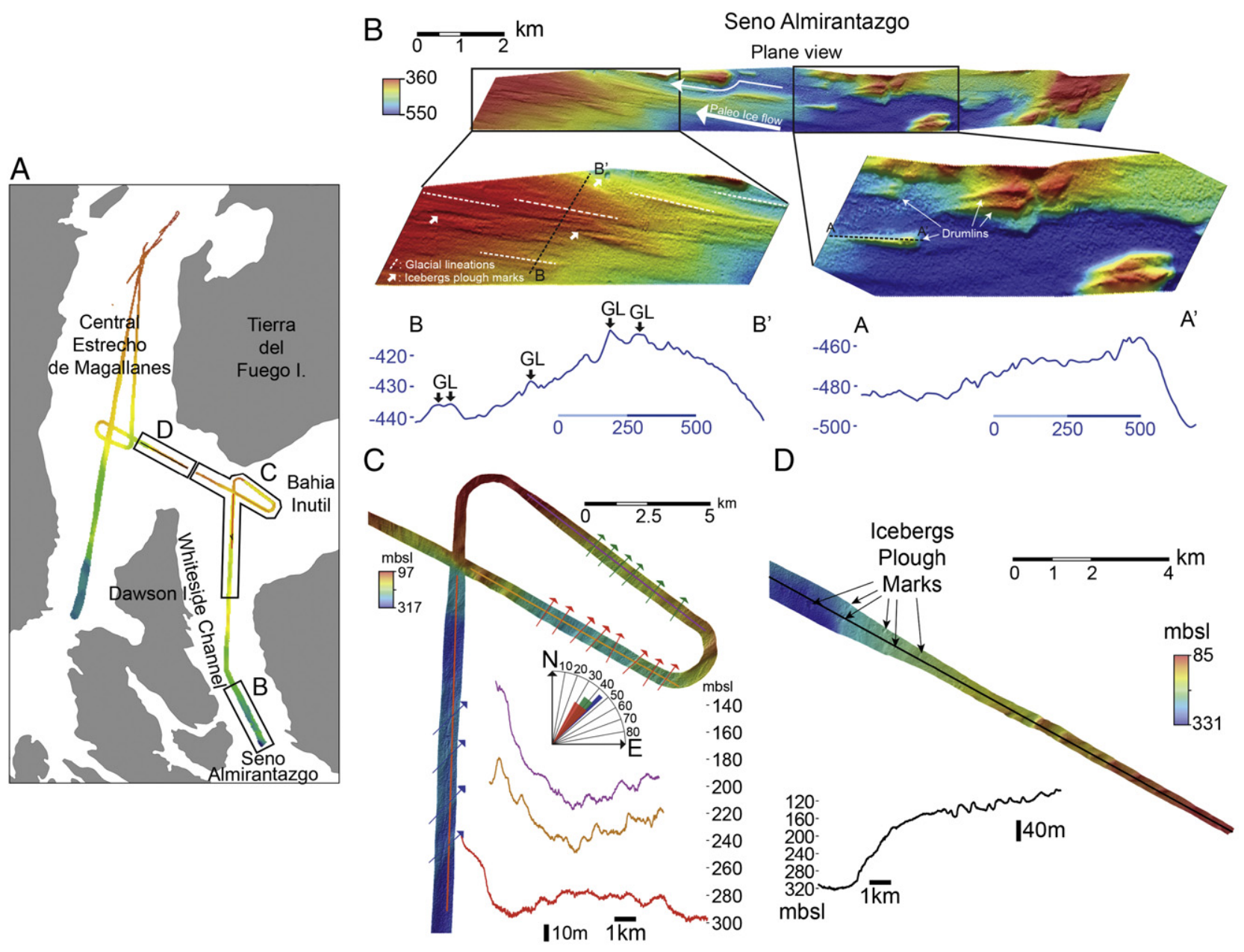

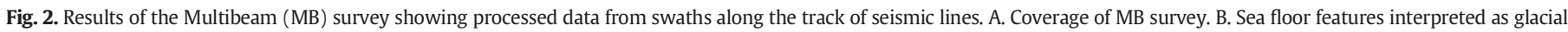

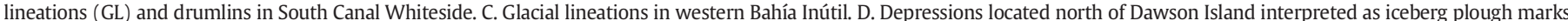
indicating the existence of a calving front during the last glacial advance into Estrecho de Magallanes.

In Whiteside Channel and western Bahía Inútil, a set of NE-oriented ridges form elongated features of varying dimensions (Fig. 2). Although only partially mapped, the consistency of orientation in adjacent multibeam swaths suggest that these ridges are up to $15-20 \mathrm{~km}$ in length. The ridge widths vary from $\sim 1 \mathrm{~km}$ in the $S W$ to $<0.5 \mathrm{~km}$ in the $\mathrm{NE}$ and heights are $<10 \mathrm{~m}$ high. A set of $\sim 2 \mathrm{~m}$ high ridges occur in the $\mathrm{NE}$ in between the larger amplitude ones.

North of Dawson Island, in the south Central Estrecho de Magallanes, irregular, well-defined depressions occur below 150 mbsl. The depressions are generally $<100 \mathrm{~m}$ wide and on west-facing slope. Additionally, a series of irregular features characterized by negative bathymetric relief occur $120-140 \mathrm{mbsl}$.

\subsection{Seismic}

Our seismic data reveal a complex seismic architecture geographically heterogeneous and better described in terms of seismic "units". We define seismic units as parts of the seismic section distinguishable based on geometric patterns and collection of seismic facies. Individual seismic "facies" are defined based on similar amplitudes and reflector patterns or lack thereof. Our seismic facies and units combine MCS and CHIRP data according to their significance for the understanding of the regional glacial history. Thicknesses are given in two-ways-travel-time milliseconds (TWTT ms) and are converted to meters using a compressional sound velocity of $1500 \mathrm{~m} / \mathrm{s}$ when describing CHIRP data.

Line 1 (Fig. 3) images Seno Almirantazgo and exhibits several distinctive facies that can be described as forming a stack of 2-4 seismic units overlying and frequently onlapping an irregular, and sometimes indistinct reflector. This irregular reflector, below which no coherent reflectors can be identified (acoustic energy drops significantly), is referred here as "acoustic basement". The uppermost Seismic Unit SU1$\mathrm{W}$ (Fig. 3) has a $\sim 10 \mathrm{~ms}$ mean thickness but can locally reach $\sim 20 \mathrm{~ms}$; it drapes the underlying units and can be recognized for $\sim 50 \mathrm{~km}$ laterally, from southern Whiteside Channel to the southern end of Seno Almirantazgo (Fig. 3). Underlying SU1 is Seismic Unit SU2-W (Fig. 3), which has a thickness of $<120 \mathrm{~ms}$, and varying seismic character. The thickness of SU2-W decreases steadily for $\sim 10 \mathrm{~km}$ southward from the northern end of Whiteside Channel to reappear discontinuously and with thicknesses generally $<10 \mathrm{~ms}$ in Seno Almirantazgo.

Below SU2-W, there is a unit of varying thickness, Seismic Unit 3 (SU3-W; Fig.4) consisting of layered subhorizontal to dipping reflectors that onlap acoustic basement. The thickness of SU3-W reaches up to $100 \mathrm{~ms}$ in some areas but is $<50 \mathrm{~ms}$ in the northern Whiteside Channel (Fig. 3b). However, a few kilometers south, SU3-W reaches a maximum thickness of $\sim 200 \mathrm{~ms}$ in two sub-basins bounded by acoustic basement promontories.

The deepest seismic unit, SU4-W, is characterized by strong reflectors defining lenticular geometries with acoustically transparent interiors resembling the top of SU2-W. The determination of SU4 internal geometry is complicated by common hyperbolic reflections generated by discontinuous, high amplitude reflectors. SU4-W is better observed in northern Whiteside Channel where it reaches $\sim 60-90 \mathrm{~ms}$ whereas in Seno Almirantazgo this unit is either not present or difficult to identify. 


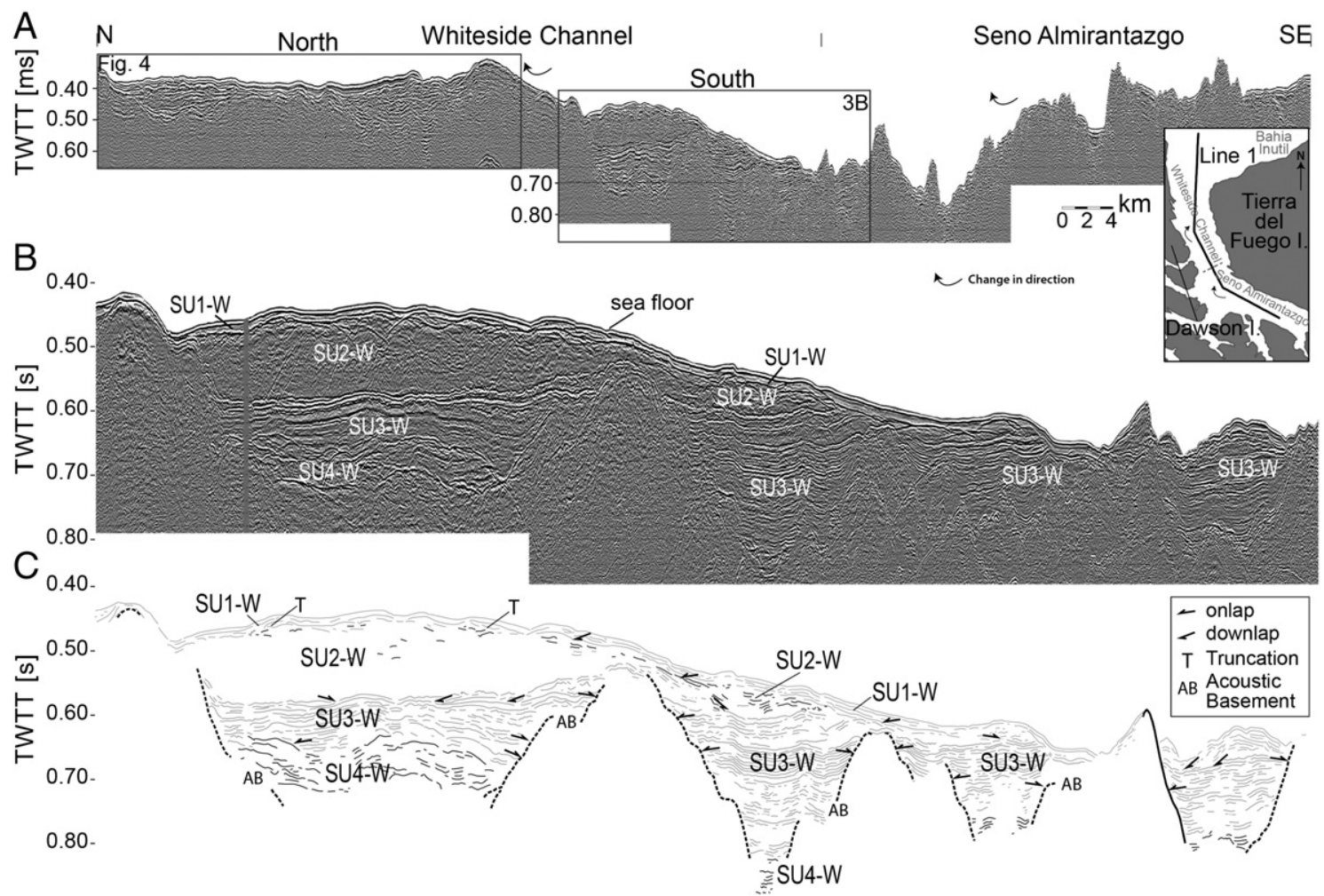

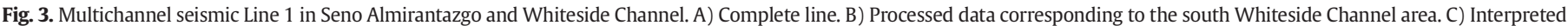

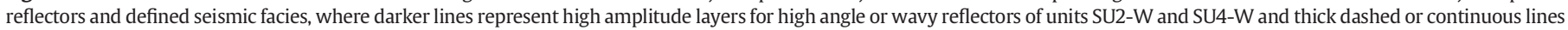
indicate acoustic basement. The main geometric relationships between reflectors near unit boundaries are indicated.

East of Dawson Island, the seismic section shows downward increasing complexity with reduced coherency and reflectors clarity. The best seismic image was obtained in the northern part of Line 1 and the western part of Line 2, and thus they are used to describe the seismic architecture of this area. In Line 1, the top of the seismic section Seismic Unit SU1-D consists of parallel reflectors that conformably drape the underlying units (Fig. 4a). CHIRP data in central Whiteside Channel show a stratified sequence of low amplitude, sub-meter spaced reflectors separated by 3-4 high-amplitude reflectors, comprising $20 \mathrm{~ms}$ of sediments (Fig. 4c). Underlying SU1-D, SU2-D is of variable thickness and characterized by dipping, downlapping reflectors. Underlying SU2-D, SU3-D is 12-15 ms thick (Fig. 4b) and characterized by low amplitude, parallel, and discontinuous reflectors that drape the underlying units. It is only observed in the MCS data in the northern part of Line 1. Below SU3-D, seismic unit SU4-D (only observed in MCS, Fig. 4b) exhibits complex internal architecture and distribution, and a variable thickness of up to $30-40 \mathrm{~ms}$. It is characterized by discontinuous, subhorizontal or dipping, high-amplitude reflectors interrupted by or bounding lower amplitude ones. Near the northern part of Line 1, SU4-D downlaps onto underlying seismic unit SU5-D (Fig. 4b). Unit SU5-D exhibits prominent dipping reflectors that pinch out or onlap onto acoustic basement. Unit SU5-D is only well defined in two areas of the northern part of Line 1 where is associated with depressions in the acoustic basement.

Line 2 was acquired along a N30E track oblique to Line 1, extending down axis of west Bahía Inútil and exhibits similar seismic architecture as Line 1 (Fig. 5). Bahía Inútil shallows rapidly to the east so that seafloor multiples obscure the section in depth allowing analysis of just the western portion of Line 2. West Bahía Inútil includes 5 seismic units. Top unit, SU1-BI, consists of parallel reflectors that drape the underlying topography and can be correlated to SU1-D. A high amplitude and irregular reflector bounds both the bottom of SU1-BI and the top of underlying seismic unit SU2-BI (Fig.6). SU2-BI is of varying thickness and underlain by a middle- to high-amplitude reflector. Sub-horizontal, sparse and discontinuous reflectors within SU2-BI appear in the northern part of Line 2. The bulk of this seismic section, however is comprised by unit SU3-BI. SU3-BI exhibits north-dipping reflectors that define distinct sub-units. The top of these reflectors is irregular but offlaps the underlying sub-unit. Part of the north-dipping reflectors of SU3-BI downlap the underlying unit, SU4-BI, but the rest conformably overlie SU4-BI (Fig.6). SU4-BI (Fig.6) consists of middle- to low-amplitude reflectors that drape the underlying topography, and sub-horizontal reflectors that onlap the previous sub-unit towards the top along a highamplitude slightly south dipping reflector. The deepest recognizable seismic unit (SU5-BI; Fig.6) is bounded on top by a high-amplitude sinusoidal reflector that can be roughly correlated with the top of SU5-D.

The Central Estrecho de Magallanes displays a complex array of seismic units that differ markedly along the axis of this passage. Although two lines were shot, Line 4, which runs N-S from the middle of this passage NE of Punta Arenas to NW of Dawson Island, offers the longest, most continuous record. For description purposes, we discuss Line 4 in three areas based on seismic character: 1) South Basin, a deep basin $(<550 \mathrm{mbsl})$ located W-NW of Dawson Island, 2) Central Basin, a shallower (<360 mbsl) basin located north of Dawson Island, and 3) North Ramp, a northward shallowing area ( 340-200 mbsl) located east of Punta Arenas.

The South Basin was imaged mainly using CHIRP with only limited coverage by the MCS system. The CHIRP data show 36-40 ms ( 55$60 \mathrm{~m}$ ) of sediments that consist of two conformable seismic units. The top unit, SU1-SB (Fig. 6b) consists of parallel and continuous reflectors finely spaced $(<0.7 \mathrm{~ms}$ or $\sim<1 \mathrm{~m})$. Four or five sub-units can be distinguished within SU1-SB, which are bound by high amplitude reflectors, and are characterized by continuous reflectors of relatively uniform amplitude. Below SU1-SB, seismic unit SU2-SB (Fig. 6b), exhibits frequent high, but variable amplitude reflectors that more coarsely spaced $(<1.3 \mathrm{~ms}$ or $\sim<2 \mathrm{~m})$ and laterally discontinuous. In contrast to SU1$\mathrm{SB}, \mathrm{SU} 2-\mathrm{SB}$ increases in thickness northward. The base of SU2-SB is a relatively thick transparent interval whose bottom boundary is discontinuous and not well defined. 


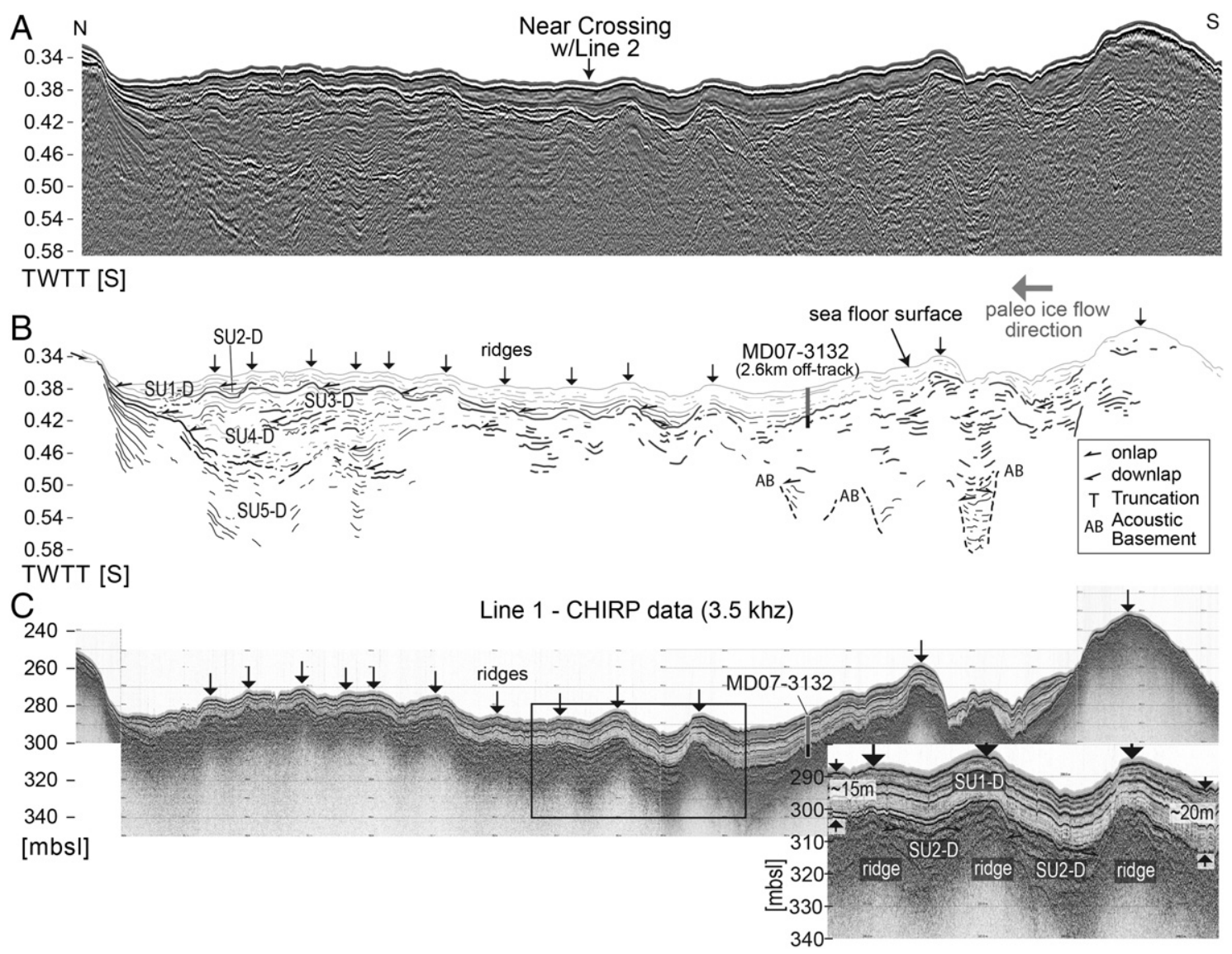

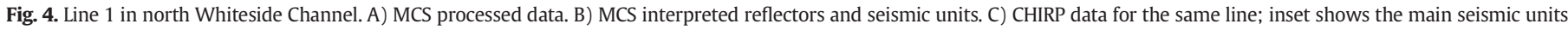

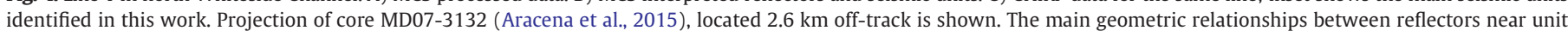
boundaries are indicated.

Both MCS and CHIRP image the Central Basin. These data show a sequence of $>40 \mathrm{~ms}(\sim 60 \mathrm{~m})$ of mostly parallel and continuous reflectors. The upper 17-18 ms ( 25-27 m) consists of two major seismic units, SU1-CB and SU2-CB (Fig. 6a). The higher resolution CHIRP data show that SU1-CB includes 4-5 sub-units similar in seismic character to the South Basin sub-units within SU1-SB. SU2-CB is only 3-4 ms $(\sim 5 \mathrm{~m})$ thick and is composed of few discontinuous reflectors that rapidly thin and disappear away from the center of the basin. Below SU2-CB, MCS data show $>30 \mathrm{~ms}(\sim 45 \mathrm{~m})$ of layered reflectors, referred as seismic unit SU3-CB (Fig. 6a), which reach a maximum observable thickness $(\sim 50 \mathrm{~m})$ near the center of the basin where reflectors exhibit coarser spacing. Unfortunately, the presence of gas or coarse sediments in the middle of the section does not allow for a clear image deeper in the section.

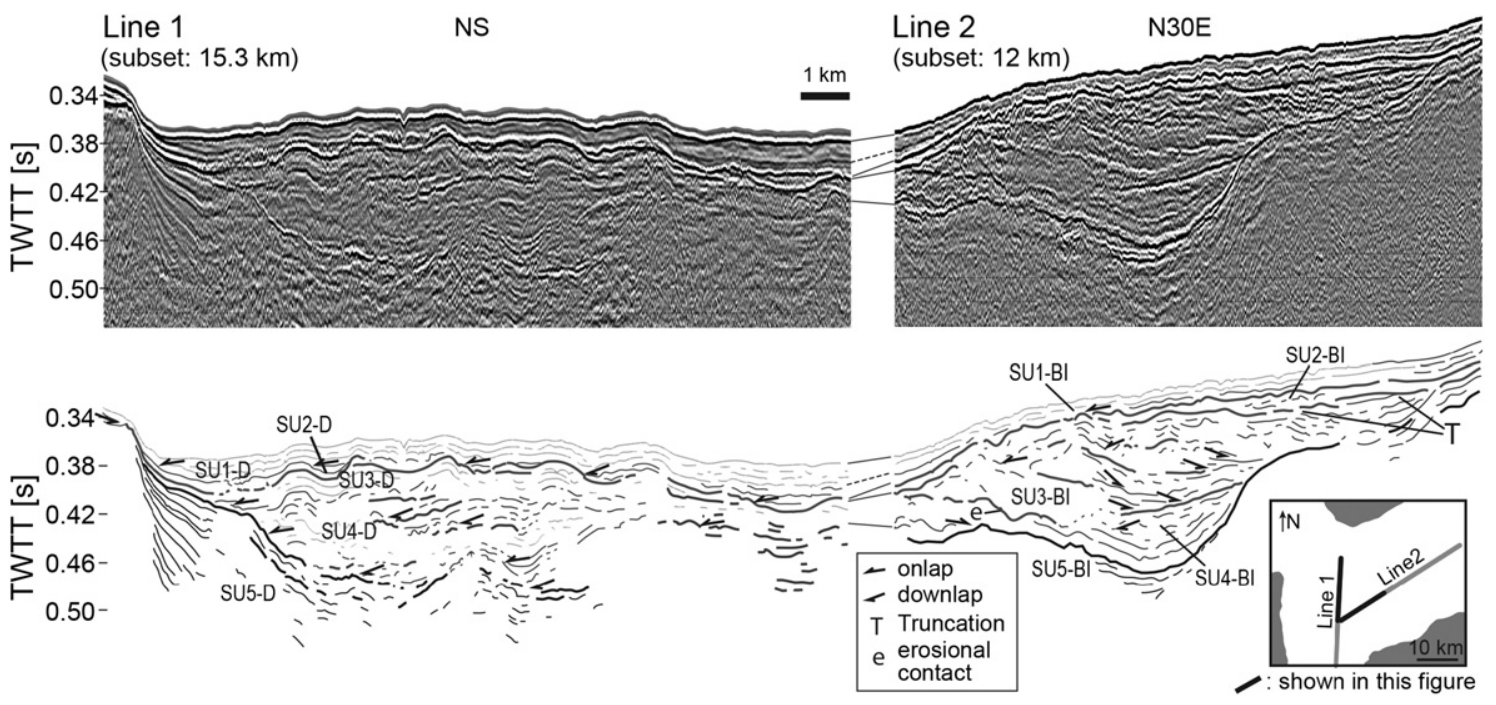

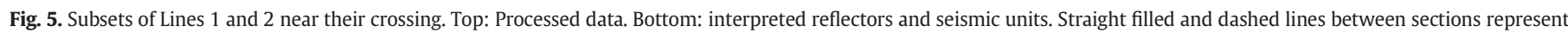
interpreted correlations. The main geometric relationships between reflectors near unit boundaries are indicated. 


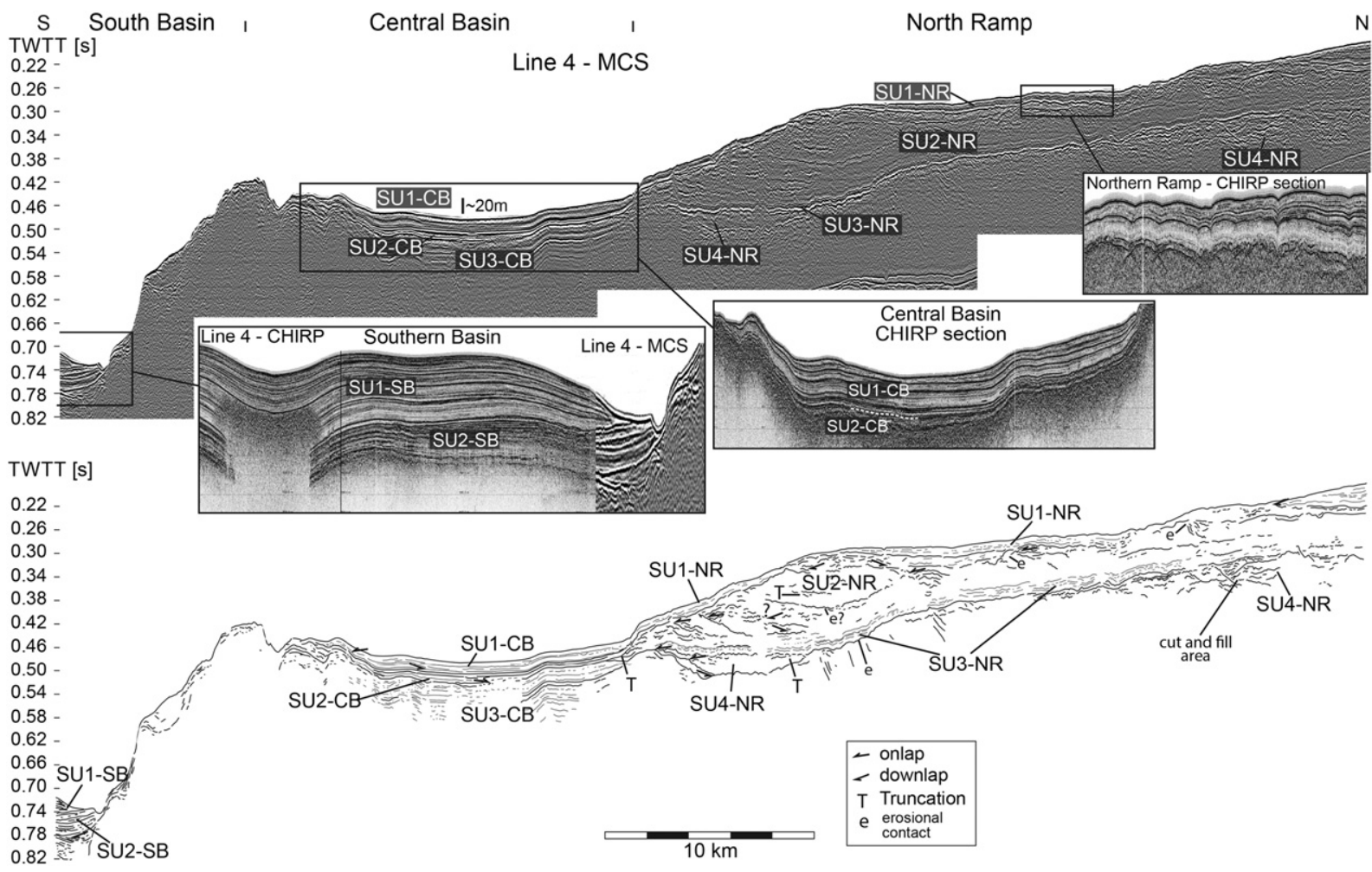

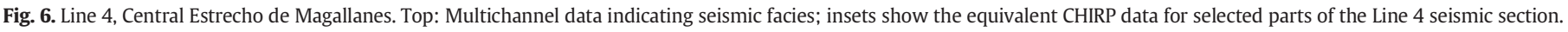
Bottom: interpreted reflectors and seismic units. The main geometric relationships between reflectors near unit boundaries are indicated.

The North Ramp area has a complex seismic architecture including layered units, dipping reflectors and acoustically transparent units, varying in organization both along section and with depth. The sequence is topped by a discontinuous unit of variable thickness, referred as seismic unit SU1-NR (Fig. 6), similar in seismic character to SU1-SB and SU1-CB. Underlying SU1-NR, SU2-NR is a vertical and lateral succession of dipping reflectors downlapping onto sub-horizontal reflectors or onlapping onto steeply dip reflectors (Fig. 6). Some dipping reflectors continue northward as sub-horizontal reflectors that drape the underlying units. Based on these geometric relationships and changes in seismic facies, a stack of 4-5 wedge-shaped sub-units that offlap northward and have restricted lateral continuity, can be recognized (Fig. 6b). The southernmost and deepest wedge-shaped sub-unit overlies SU3-CB in the northern part of the Central Basin (Fig. 6b). The two uppermost wedge-shaped sub-units, are thinner than the rest and appear stacked in the northern part of Line 4.

Underlying SU2-NR, SU3-NR composed of parallel and discontinuous reflectors that drape the underlying topography with nearly constant thickness (6-7 ms or $\sim 10 \mathrm{~m}$ ) (Fig. 6). In the southern part of the North Ramp, SU3-NR is underlain by SU4-NR which is composed of dipping reflectors distributed within a basin shaped area delimited by a high amplitude reflector (Fig. 6). In contrast, in the northern part of the North Ramp, SU3-NR is underlain by SU5-NR which is a unit of complex internal architecture (Fig. 6) including high-dip reflectors, onlapping and offlapping facies, and irregular reflectors with no evident bottom boundary.

\section{Interpretation}

The elongated features that occur in the south Whiteside Channel, oriented parallel to its axis (Fig. 2b), are interpreted as the expression of glacial lineations formed by grounded glaciers. This interpretation is based on the similarity (shape, dimensions) with features described elsewhere (e.g. Boulton and Clark, 1990), but particularly in the Antarctic Peninsula (Heroy and Anderson, 2005; King et al., 2009), where glacial lineations are found within shelf crossing troughs which have crest to crest spacing of a few $100 \mathrm{~s} \mathrm{~m}$ and amplitudes $<20 \mathrm{~m}$. In Whiteside Channel, crest to crest spacing is usually less than $\sim 500 \mathrm{~m}$ but near the southern end of Bahía Inútil can reach up to $\sim 1000 \mathrm{~m}$, whereas amplitudes are $<5-7 \mathrm{~m}$ (Figs. $3 \mathrm{~b}, \mathrm{c}$ and 4 ). The directionality of the paleo ice flow is given by a set of asymmetric features (Fig. 3b) interpreted as bedrock cored drumlins due to their morphology (Fig. 2b) and the MCS imaging of acoustic basement beneath their surface which we interpret as bedrock (Fig. 3b). The swath bathymetry data and depth profiles along these drumlins indicate that the high angle slope faces south, thus indicating the upstream direction of the paleo-ice flow. The relative spatial organization of glacial lineations and drumlins resembles that of the Antarctic Peninsula continental shelf, with glacial lineation occurring just downstream from drumlins in areas of high sediment accumulation, and drumlins occurring in areas of variable or sparse sediment cover and rugged bathymetry (Fig. 2b; Heroy and Anderson, 2005; Wellner et al., 2006). Farther north, the ridges mapped in northern Whiteside Channel and western Bahía Inútil (Fig. 2c), are interpreted as expressions of glacial lineations indicating ice flow directed towards the northeast, into Bahía Inútil (Fig. 2a).

We note that the described sea floor morphology is in fact the expression of features buried under several meters of sediment. In southern Whiteside Channel, parallel, moderate-low amplitude reflectors that drape the underlying topography, representing $15-30 \mathrm{~m}$ of stratified sediments, overlie a series of irregular and high amplitude reflectors forming the top of SU2-W, which conform the irregular surface that defines the geomorphological features mapped on the sea floor. Thus, the glacial lineations are constructed within the coarser (higher amplitude reflectors) sediments that form the irregular top of SU2-W. This relationship is also the case of a prominent drumlin mapped farther south in Line 1 (Fig. 3b,c). Glacial lineations are constructed subglacially involving different kinds of glacial diamicton, such as coarse grain and/ or stiff till usually of massive character (e.g. O'Cofaigh et al., 2005), which is consistent with the lack of or minimal stratal organization, 
diffraction hyperbolas and high amplitude reflectors that characterize the top of SU2-W.

In northern Whiteside Channel, the glacial ridges seen on the sea floor can be traced down in the section to undulations and dipping reflectors in the lower part of SU3-D, about $20 \mathrm{~m}$ below the sea floor. Overlying SU3-D, relatively high amplitude reflectors are interpreted as coarse sediments and show onlapping/downlapping geometries in the lower part, and parallel conformable reflectors in the upper part (SU2-D; Fig. 4), consistent with the transition from dense gravity driven to settling-from-suspension deposition. This interpretation implies a change in the glacial depositional environment, from grounding line proximal (lower part of SU2-D; Fig. 4) to more distal proglacial (upper part of SU2-D; Fig. 4). Above these sediments, a stratified sequence of pelagic sediments (SU1-D) drape the underlying topography, similarly to SU1-W farther south. Confirmation of these interpretations comes from an $22 \mathrm{~m}$ long sediment core in Whiteside Channel studied by Aracena et al. (2015); core MD07-3132; Figs. 1,5) and obtained $\sim 2.6 \mathrm{~km}$ to the west of Line 1. Core MD07-3132 sampled, from top to bottom: 1) 15 m of fine sediments including several tephra layers (Aracena et al., 2015), which we correlate with the stratified pelagic sediments of SU1-D (Fig. 4), 2) $\sim 5$ m of sediments with increasing clay content and sandy layers corresponding to the coarser stratified sediments of the upper part of SU2-D (Fig. 4), and 3) 2 m of dropstone bearing diamictite, which we correlate with the coarse dipping strata of SU2-D. The oldest date reported by Aracena et al. (2015), 10.410.7 cal kyr BP was obtained at a core depth of $1475 \mathrm{~cm}$ which we correlate with the lower part of the stratified sediments of SU1-D; our data extend the geographic reach of the results of Aracena et al. (2015), and indicate that Whiteside Channel has been subject of pelagic marine sedimentation with no glacial influence since $\sim 11 \mathrm{ka}$. Unfortunately, Aracena et al. (2015) found no datable materials in core MD07-3132 below 15 mbsf, and thus, it cannot be used to constrain the age of what we interpret as glacial proximal sediments.

Underlying the surficial stratified units in south Whiteside Channel, unit SU2-W is interpreted as massive tillites or highly deformed sediments, deposited and/or deformed under subglacial conditions. SU2W thickens towards the northern part of southern Whiteside Channel, where successive basement highs form small basins that have been over filled by the accumulation of several sedimentary units (SU1-4W; Fig. 4). Thus, the shallowing of the bathymetry in southern Whiteside Channel near Dawson Island (Figs. 1 and 3) is the result of high sediment accumulation rates.

Underlying SU2-W, the top of SU3-W (Fig. 3) characterized by a series of dipping reflectors with internal chaotic facies that onlap basement highs and downlap the underlying units, is interpreted as mass wasting deposits (e.g. turbidites, gravity flows, and slope related remobilization deposits). Similar seismic facies farther south in the Marinelli Glacier area, are overlain by progradational and aggradational glacimarine sediments, and were interpreted as morainal bank deposits formed during glacier advance and temporary stabilization at basement pinning points (Fernandez et al., 2011). Thus we interpret the top of SU3-W as representing the first stage of glacial sediment deposition during a glacial advance in this area. However, in contrast to Marinelli Glacier area, where these facies downlap onto acoustic basement, in Whiteside Channel they downlap onto parallel subhorizontal reflectors interpreted as stratified fine sediments that were deposited prior to the glacial deposits of SU2-W, and thus represent interstadial sediment deposition. The bottom unit of the southern Whiteside Channel section, SU4-W, resembles the top of SU2-W with dipping, high-amplitude and complex seismic architecture and is interpreted as glacial or glacially deformed deposits.

In summary, the seismic section imaging southern Whiteside Channel is interpreted as two stacked glacial-interglacial sedimentary sequences (SU4-W-SU3-W and SU2-W-SU1-W; Fig. 3). If the same interpretation criteria is applied to the seismic section imaging northern Whiteside Channel, then the layered facies of SU1-D and SU5-D would correspond to interstadial sediments, while the complex seismic facies composing SU3-D and SU4-D would represent glacial or glacially deformed sediments. The seismic architecture of combined facies SU3-D and SU4-D reveal at least two angular unconformities that separate dipping and discontinuous reflectors that downlap onto the underlying sub-horizontal or irregular boundary, respectively. Dipping facies might then represent either proximal or mass wasting deposition of glacial or glacially influenced sediments, configuring a scenario of possibly three distinct glacial events. The lack of stratified sub-horizontal layers associated with distal or pelagic deposition suggests that these events were short lived and represented small in-stadial glacial variations; an alternative explanation is that interstadial hemi-pelagic sediments were eroded away by the subsequent glacial advances. It follows then that the sedimentary record imaged in the northern Whiteside Channel represents 1 entire glacial-interglacial cycle (SU3-D-SU4-D and SU1-DSU2-D respectively; Fig. 3), overlying the interstadial sediments of SU5$\mathrm{D}$ (Fig. 3). Since we do not expect major differences between the glacial history of the southern and northern Whiteside Channel, and a deeper glacial unit seems to be missing, we conclude that either the stratigraphic sequence in the northern Whiteside Channel is incomplete (there were no glacial or glacially influenced sediments deposited previous to SU5-D) or not imaged by our MCS array.

In western Bahía Inútil, Line 2 shows a complex seismic architecture and at least two possible erosional unconformities and one angular unconformity that define distinctive seismic units (Fig. 5). Line 2 does not cross Line 1 but their proximity and similar array of seismic facies (Fig. 5) facilitates the interpretation of Line 2 by correlation of seismic units. Units SU1-BI and SU2-BI are interpreted as interstadial layered draping sediments and correlate with SU1-D and SU2-D respectively. Unit SU3-BI, characterized by wavy and high angle dipping reflectors showing progradational geometries, is interpreted as stadial glacial sediments, and correlates with SU3-D and perhaps the top of SU4-D (Fig. 5). It is unclear if SU4-BI, formed by parallel reflectors infilling a small basin, correlates with the bottom part of SU4-D or with SU5-D but is interpreted as representing interstadial sediments (Fig. 5). Only a few reflectors were mapped within SU5-BI, which does not allow an unambiguous interpretation. Thus, similar to the section imaged in Line 1, western Bahía Inútil sediments are interpreted to represent an interstadial-glacial-Interstadial sequence (SU5-BI(?)-SU4-BI, SU3-BI-SU2-BISU1-BI respectively; Fig. 5).

In the Estrecho de Magallanes, the remarkable differences in seismic architecture between the North Ramp and the South and Central basins is interpreted as result of two likely related points: 1) Line 4 runs along the direction of past northward ice flow and the North Ramp part of Line 4 is where previous studies inferred the existence of submarine moraines recording glacier extent variations associated with glacial limit 'D' ( 17-18 ka; McCulloch et al., 2005a, 2005b; Kaplan et al., 2008); 2 ) the bedrock erosional surface (acoustic basement; Fig. 6), probably carved by multiple glaciations on Meso-Cenozoic sedimentary rocks, shallows northwardly in the North Ramp, and has a complex geometry (not totally resolved in our seismic data) including a shallow sill that separates the South and Central basins.

The architecture of the North Ramp seismic section is interpreted as a complex of high-energy, glacial proximal, and glacial distal or pelagic sediments overlying the acoustic basement. SU4-NR is interpreted as glacial proximal sediments that in the southern part of the ramp, fill a small basin carved into acoustic basement. In the northern part of the basin, the architecture of SU4-NR is suggestive of deposition in cut and fill channels which we interpret as a morainal bank complex. It is unclear whether or not the high amplitude reflector at the top of SU4-NR represents a conformable erosional surface and/or lag deposit. Overlying sediments corresponding to SU3-NR are stratified and drape the underlying topography and so were deposited from suspended sediments in a distal or proglacial environment. Overlying SU3-NR, is SU2-NR whose architecture can be described as an offlapping stack of wedge shaped units intercalated or laterally connected to sub-horizontal 
layered sediments. The wedge-shaped units are interpreted as remnants of morainal banks formed as earlier glaciers successively grounded in this area. The lack of similar deposits in the South and Central basins suggests that ice did not ground in these areas during the last glacial advance. The interpretation is that glacier advance onto the Central Estrecho de Magallanes proceeded as follows: 1 ) ice expanded and was able to overcome the deep South Basin and shallower Central Basin, perhaps by grounding on the shallower sides of the strait, 2) it encountered a natural pinning point in the shallower North Ramp where it stabilized by grounding and forming morainal banks. The middle- to low-amplitude reflections from draping or sub-horizontal layered facies associated with the morainal banks are interpreted, in this context, as either distal morainal bank or proglacial deposits (Fig. 6). The evolution of this complex of morainal banks is interpreted as follows: 1) the oldest two morainal banks shallowed the water depth of the North Ramp by at least 60-70 m (Fig. 6), thus decreasing the bathymetric gradient and allowing the formation of more distal morainal banks at slightly shallower depths. The two youngest morainal banks were deposited when the slope was nearly sub-horizontal so depth variation in this part of the ramp was minimal. This interpretation would explain the development of shallow morainal banks at different locations along Line 4, all belonging probably to the same glacial event.

In the South and Central basins the seismic architecture is characterized by an aggradational sequence of two and three distinguishable sedimentary facies respectively (SU1,2-SB and SU1,2,3-CB; Fig. 6), composed mostly, of conformable strata. The top unit in both basins (SU1-SB/CB; Fig. 6) share similar architecture with middle- to low-amplitude parallel reflectors interpreted as settling from suspended sediments interbedded with at least 3-4 conformable high-amplitude reflectors. Expedition "MD159-Pachiderme" (hereinafter referred as "Pachiderme") in 2007 obtained several cores at a single site in each of these basins (Kissel, 2007a, Kissel, 2007b; Aracena et al., 2015). Although none of core sites are located directly along the track of our seismic lines (2.4 and $6.5 \mathrm{~km}$ off track for the South and Central basins respectively), the Pachiderme CHIRP sections show, despite difference in thickness, a similar set of seismic units as imaged by Line 4 (Kissel, 2007a, 2007b). This similarity is expected since there is no known geological factors that would affect the lateral continuity of sedimentary units within each basin. The cored sediments are described as clays and silt bearing clays with abundant organic matter and occasional shells, and with a thick $(10-17 \mathrm{~cm})$ light color tephra layer that occur at different depths along each core. This tephra layer is correlated with a high amplitude reflector and interpreted as corresponding to Mt. Burney's 4.2 kyr eruption (Kissel, 2007a, 2007b). This correlation allows, based on a linear accumulation rate, us to estimate an age of 9.5$13.7 \mathrm{kyr}$ for the beginning of the accumulation of SU1-SB and SU1-CB. Thus, the cumulative evidence indicates that SU1-SB and SU1-CB represent Holocene pelagic sediments similar to SU1-D.

SU2-SB and SU2-CB were not sampled by the Pachiderme expedition and so there is no direct observation of their constituent sediments. However, since these units are conformably overlain by SU1-SB and $\mathrm{SU} 1-\mathrm{CB}$, we interpret them as being of Late Pleistocene age. The higher amplitude of SU2-SB and SU2-CB reflectors and their well-defined stratification indicate that they consist of coarser sediments. Since there are no rivers, nor glaciers of significance in the area, the source of these relatively coarser sediments must be related to past glacier proximity. We observe also that in the South Basin SU2-SB thickens northward while the overlying unit, SU1-SB, thickens southward suggesting that they accumulated under markedly different sedimentary conditions. Thus, we interpret that both SU2-SB and SU2-CB were accumulated in a proglacial environment where coarse glacial sediments were delivered by dense sediment plumes and/or icebergs.

The interpretation of SU3-CB, which was only imaged by the MCS system, is problematic. At least part of its seismic architecture closely resembles that of SU2-CB, raising concerns of local peg-leg multiples (Fig. 6). In the South Basin, only a small portion of Line 4 imaged seismic facies beneath SU2-SB, which include a transparent facies overlying coarsely stratified sediments. This observation might indicate proximal glacial deposition that would be expected given the interpretation of the above seismic units. However, we regard any interpretation of unit SU3-CB and facies beneath SU2-SB as requiring additional data to be clarified.

The sea floor features mapped north of Dawson Island are interpreted as the expression of icebergs plough marks and thus represent an ancient proglacial environment. We lack direct data to assign an age to these features but as they are covered by post-glacial to Holocene pelagic sediments, we interpret them as relicts of the waning stage of the last regional glacial advance that covered this part of the Estrecho de Magallanes, which would correspond to Late Glacial 'D' at 17 ka. The bathymetry gradient suggests that the paleo-ice front from which these icebergs calved corresponded to the western lobe.

\section{Discussion}

\subsection{The marine glacial-interglacial record of Magallanes}

The sedimentary sections of Central Estrecho de Magallanes, Whiteside Channel, Bahía Inútil and Seno Almirantazgo consist of a complex array of seismic facies. We recognize two main types of seismic facies: a) parallel reflectors with no internal complex geometries, that either drape underlying topography, or are sub-horizontal, and b) high angle or sinuous reflectors, usually of high amplitude, with poor lateral continuity and usually associated with transparent intervals and point source diffractions. We interpret (a) facies as either pelagic or glacimarine distal stratified sediments accumulated in a proglacial environment, and are referred as type I facies (Fig. 7). The facies described in (b), are interpreted as ice proximal and/or subglacial sediments (i.e. deposited or deformed subglacially), and are referred as type II facies (Fig. 7). This distinction is useful as a seismic unit

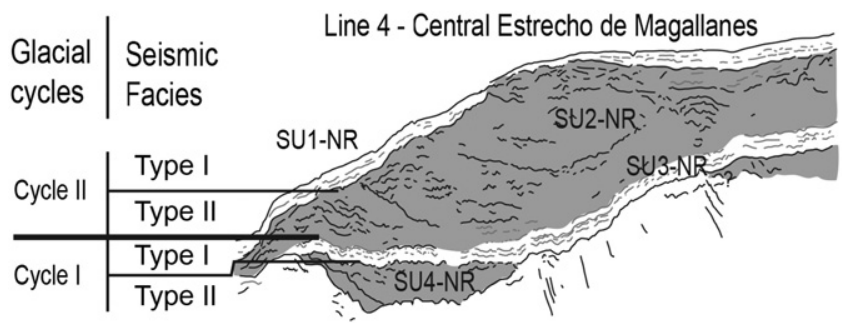

Line 1 - North Whiteside Channel

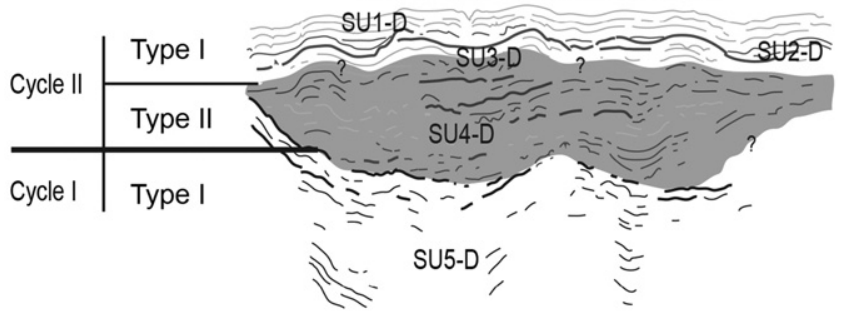

Line 1 - South Whiteside Channel

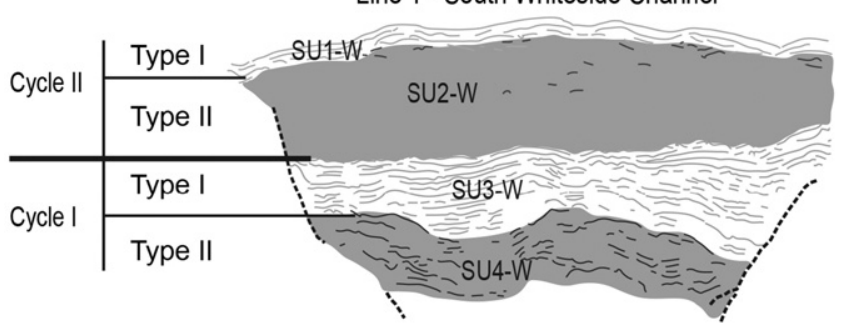

Fig. 7. Seismic facies and glacial cycles identified in the marine sedimentary record of the Magallanes Region. 
dominated by type I facies can be interpreted as interstadial or interglacial sediments, while a seismic unit dominated by type II facies can be interpreted as stadial or glacial sediments. This interpretation assumes that during interstadial or interglacial periods, glaciers retreated into the cordilleran areas (e.g. McCulloch et al., 2005a), so that most sediments deposited in deep basins settled from sediment plumes or were transported by turbidites or hyperpycnal flows (Fernandez et al., 2011). The result would be the infilling of deep basins with ponded or conformable strata (Syvitski, 1989). During stadial or glacial periods on the other hand, glaciers would have advanced into deep fjords and troughs where coarse glacial proximal (high-energy environment) sediments were deposited in subglacial depositional environments in the form of morainal banks or massive glacial diamictites, or correspond to deformed strata. Thus, the seismic facies associated with glacial periods can be complex and include dipping strata (e.g. morainal bank progradation), cut and fill geometries, erosional unconformities etc. (Powell, 1984; Powell and Molnia, 1989; Stravers and Powell, 1997).

Based on this interpretation framework the studied seismic sections represent at least two major glacial cycles. The oldest cycle, cycle I (Fig. 7 ), is represented in southern Whiteside Channel and Seno Almirantazgo by SU4-W type II facies and SU3-W, SU5-D and SU5-BI type I facies (Figs. 4, 5, 6), and in Central Estrecho de Magallanes, by SU4-NR type II and SU3-NR type I facies (Fig. 6). The youngest cycle, cycle II (Fig. 7), is represented in southern Whiteside Channel, Seno Almirantazgo and Bahía Inútil by SU2-W, SU3/4-D, SU3/4-BI type II facies and SU1-W, SU1/2-D and SU1/2-BI type I facies (Figs. 4, 5, 6), and in Central Estrecho de Magallanes, by SU1/2-SB-CB-NR type I facies (Fig. 6).

The ages of the sediments associated with cycles I and II are difficult to determine given the scarcity of dated sediment cores in the area. The only marine sediments that have been dated in the study area correspond to type I facies from cycle II in the South Basin of the Estrecho de Magallanes and Whiteside Channel. These sediments represent Holocene pelagic sedimentation and are dated to $~ 9.5-13.7 \mathrm{kyr}$ and $\sim 11 \mathrm{ka}$. Underlying glacial sediments described as type II facies of cycle II have not been directly dated and might prove difficult to do so with current techniques; however, we note that there are several areas where these sediments are within the reach of conventional coring devices (Fig. 7). We also note that type II facies might actually represent repeated glacier variations within a glacial cycle or stadial period, since erosional unconformities might be present but difficult to identify. However, we hypothesize that Cycle II corresponds to the last glacial cycle, and that type II facies are associated with the last glaciation. If this is the case, some of the main characteristics observed in the seismic images, such as stacked wedge-like units in Central Estrecho de Magallanes and the unconformity separating two consecutive type II facies in the Whiteside Channel sequence (SU3-D and SU4-D), are due to incycle glacier variations or late glacial events.

We do not possess any direct evidence to assign an age to cycle I sediments. However, taking into account the low preservation potential of sedimentary facies in glaciated environments, we find it likely that cycle I corresponds to the previous to last glacial cycle.

\subsection{Significance for the recent glacial history of Magallanes}

Our combined multibeam and seismic data demonstrate the existence of grounded ice during the last glacial cycle along the two main paths occupied by the ice lobes that flowed from Cordillera Darwin into the lowlands of the Estrecho de Magallanes and Tierra del Fuego. As ice grounded on the deeper areas of Seno Almirantazgo and Whiteside Channel and the relatively shallow areas of the Estrecho de Magallanes, glaciers formed the imaged drumlins (Fig. 2), lineations (Fig. 2), and buried morainal banks (Figs. 3, 6). It is possible though, that there were intervals of time when ice was not grounded in the deeper areas as calving glaciers usually experience variations in length and thickness even during climate conditions favorable for glacier growth (e.g., Meier and Post, 1987; Post, 1975). However, it is reasonable to assume that ice lobes were mostly grounded when they reached near glacial maximum extent, which would correspond to glacial limit 'B' ( 31-23 ka) and the slightly less extensive glacial limit 'C' ( > 22$20 \mathrm{ka})$. Since the observed glacial morphological and sedimentary features exist within the limits of these glacial advances and the top seismic units (type I cycle II; Fig. 7) didn't exist at that time, it is likely that these features were being constructed or shaped at least until ice retreated from limit ' $C$ '. The question that remains is whether or not these features were also modified or constructed during regional Late Glacial advances 'D' and 'E' ( 17-18 ka and 16-12 ka). Advance 'D' moraines, located along the coast of Bahía Inútil and Estrecho de Magallanes, have been well studied and dated using cosmogenic isotopes (McCulloch et al., 2005a; Kaplan et al., 2008), and although some doubts exist with respect to the validity of the published dates (Darvill et al., 2015), the general agreement is that ice retreated from limit ' $D$ ' not later than $17 \mathrm{ka}$. A maximum deglaciation age of $\sim 22-23 \mathrm{ka}$ is given by radiocarbon dates on sediment cores in Bahía Inútil and Whiteside Channel (Anderson and Archer, 1999). Regardless of the uncertainty on the timing of expansion and waning of the glaciers that left limit ' $D$ ' moraines, their position indicates that all areas where we mapped subglacial features, were covered by ice during this stage and so it is possible that they were active.

The most recent regional Late Glacial advance proposed in the literature, advance 'E' (16-12 ka; Clapperton, 2000; McCulloch et al., 2005a, 2005b; Sugden et al., 2005; Kaplan et al., 2008), has received renewed attention. This interest is due to new evidence (e.g. Boyd et al., 2008; Hall et al., 2013) suggesting that advance E either did not take place, or was of much lesser extent than indicated by earlier studies. The relevance of this discussion lies in the proposed timing of advance $\mathrm{E}$ as it coincides with the ACR. A significant regional glacial growth in the Magallanes Region in tandem with the ACR would indicate a strong influence of temperature variations in the Antarctic continent on the environment of southern South America. That climate changed and glaciers advanced during the ACR has been suggested by several studies (Kilian et al., 2007a, 2007b; Moreno et al., 2009; García et al., 2012; Kilian and Lamy, 2012). Most notably in Torres del Paine National Park, $400 \mathrm{~km}$ NW of our study area, geomorphology and cosmogenic isotopes dating of frontal and terminal moraines indicate that glacier fronts were located $\sim 5$ or more kilometers from their present day position during the ACR (García et al., 2012). However, Torres del Paine ACR-ice lobes were hardly comparable to the Magallanes ice lobes. They were 5-6 times smaller in area, and flowed over relatively gentle land topography as opposed to the deep and rugged sea floor of Magallanes with its now submerged paleo-ice paths. In the Magallanes Region, the proposed ACR terminal moraines (limit 'E') are $>100 \mathrm{~km}$ from present day ice fronts. The geometry of the ice paths sufficient to reach limit ' $E$ ' moraines requires paleo-ice lobes $\sim>15 \mathrm{~km}$ wide and $\sim 500 \mathrm{~m}$ thick to overcome the deep (present day water depths: 500-600 m) and irregular Seno Almirantazgo and Estrecho de Magallanes basins. Thus, in order to have the proposed ACR glacial advance into the Estrecho de Magallanes and Whiteside Channel and form limit E moraines, requires the buildup (or stabilization) of a great volume of ice of relatively low profile to occupy the "Almirantazgo-Whiteside trough" (Fig. 1), and requires an ice flux high enough to keep up with ice loss along a $\sim 25 \mathrm{~km}$ marine calving front. We infer that to meet these conditions the regional climate had to be cold and humid in order to keep a low elevation equilibrium line altitude (ELA). The presumption of a relatively cold climate in the Magallanes Region during the ACR is consistent with pollen records from the area that show a dominance of steppe tundra taxa (McCulloch and Davies, 2001; Markgraf and Huber, 2010; Mansilla et al., 2016), however is not observed in sea surface temperature from offshore records (53 S; Caniupan et al., 2011). Increasing humidity in the region during the time of the ACR is supported by a steady increase in Nothofagus in the pollen record from Punta Yartou (Fig. 1; Mansilla et al., 2016), however, this pattern is not observed in other sites (Kilian and Lamy, 2012). Thus 
the available climate records in the Magallanes Region do not unambiguously support the cold and humid conditions required for an extensive glacial advance at the time of the ACR in the Estrecho de Magallanes area.

We found no evidence of submerged or buried morainal banks that could constitute the continuation across Whiteside Channel of the glacial features referred as glacial limit 'E' described on Dawson I. in previous studies (Clapperton, 1995, Bentley et al., 2005; McCulloch et al., 2005a,2005b; Fig. 1). In fact, the youngest glacial morphological features identified in the bathymetry and seismic sections of the area, are glacial lineations that extend parallel to the assumed ACR paleo ice flow direction. This finding suggests that the deglaciation of the northern part of Whiteside Channel and western Bahía Inútil proceeded rapidly with no significant glacial still stands. Thus, the features mapped in Dawson I. may be older than previously thought since, according to our interpretations, the last time that part of the island could have been in contact with ice was during the retreat of Magallanes ice lobes from limit 'D', at least $17 \mathrm{ka}$ (Fig. 8). This inference is consistent with other recently published data: Boyd et al. (2008) radiocarbon data indicate marine conditions in south Seno Almirantazgo by $15.5 \mathrm{ka}$, Hall et al. (2013) report deglaciation ages of $\sim 16.4-16.8 \mathrm{ka}$ from low elevation peat bogs along the west coast of Seno Almirantazgo, Mansilla et al. (2016) shows that an area at 51 masl near Puerto Yartou, in the eastern coast of Whiteside Channel (Fig. 1), was deglaciated at least by 18 ka, and Darvill et al. (2015) proposes in a geomorphological study that limit 'D', 'C' and 'B' erratic boulders belong to the same glacial event, which

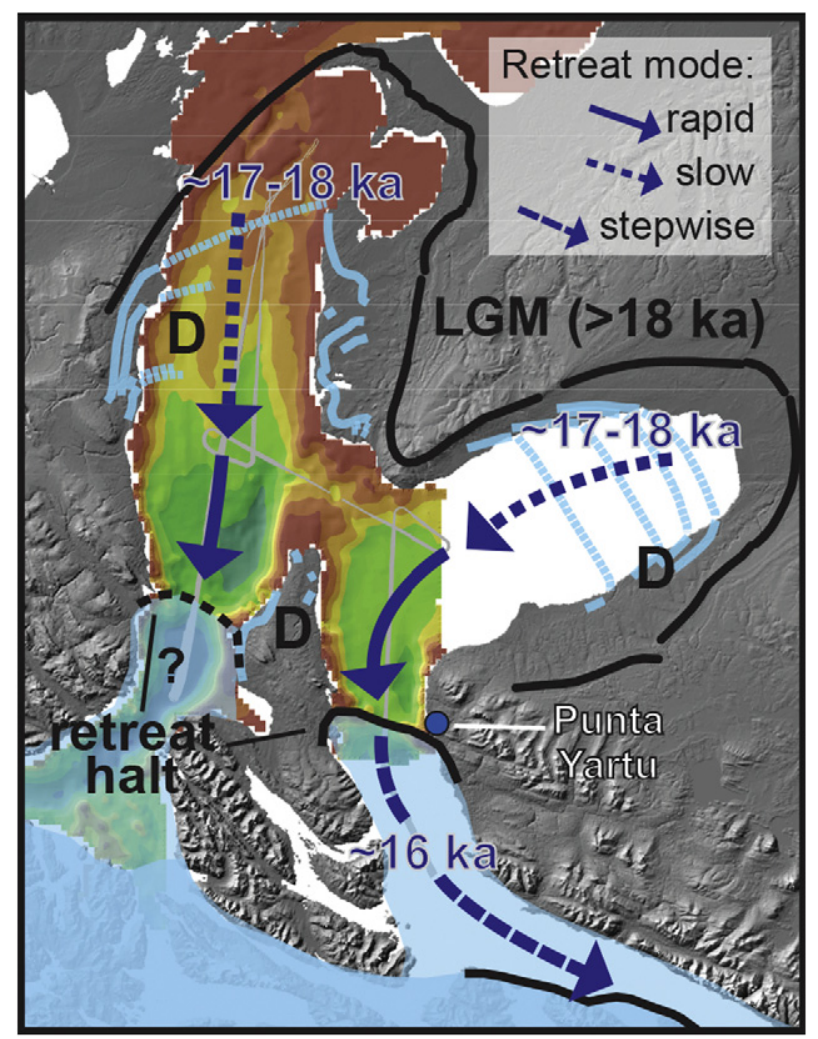

Fig. 8. Proposed timing and mode of retreat of the deglaciation of the main marine inlets in the Estrecho de Magallanes area. Slow ice retreat is evidenced by a series of moraines, interpreted here as recessional ( 17-18 ka; see text for references). This is followed by faster retreat over deeper areas where no submerge moraines were found until the ice margin stabilizes at a channel constriction near Punta Yartu in Whiteside Channel; the existence of a similar constriction and evidence of gravity driven sediments associated with it along the Central Estrecho de Magallanes, suggest that this was also the case for the western ice lobe. From this constriction and based on the highly irregular bathymetry that offer a series of shallow pinning points (Fig. 3), we suggest that grounding line retreat was in a stepwise fashion, reaching the area of Ainsworth Bay 16 ka (Boyd et al., 2008; Hall et al., 2013). would imply that limit ' $\mathrm{D}$ ' corresponds to the waning stage of the LGM. Two conclusions can be drawn from the available cumulative terrestrial and marine evidence: a) ice volume had decreased significantly and glaciers had retreated to the Cordilleran fjords before the time of the ACR; and b) limit 'D' moraines represent the remains of the last deglaciation of Bahía Inútil, Whiteside Channel and Central Estrecho de Magallanes (Fig. 8). The indication that deglacial atmospheric and ocean warming started $\sim 18 \mathrm{ka}$ from Antarctic ice core records (Pedro et al., 2011) and offshore the Magallanes Region (Caniupan et al., 2011), strongly suggest that the deglaciation of the Magallanes region was driven by increasing regional temperatures.

There are, however, indications that glaciers stabilized near Punta Yartou (Fig. 1) at some point during the deglaciation (Fig. 8). Indeed, our data show about $90 \mathrm{~m}$ of massive sediments (type II) corresponding to seismic unit SU2-W (Fig. 3). These sediments accumulated near a deep cut on an otherwise shallow promontory that marks the boundary between the deeper southern Whiteside Channel and the shallower northern Whiteside Channel (Fig. 1). This submarine promontory is parallel to the NWW oriented hills formed by stratified Cretaceous-Eocene sedimentary rocks that crop out in Tierra del Fuego and Dawson islands (SERNAGEOMIN, 2003). Line 1 was acquired through this deep cut where it shows acoustic basement buried only by a few meters of stratified sediment. The available bathymetry indicates the existence of an axial shallow area bounded by deep parallel basins on both sides. Since the seismic section shows that the sea floor morphology in this area is dominated by sediment accumulation, we infer that sediment thickness (SU2-W; Fig. 3) decreases away from the axis of southern Whiteside Channel. Seismic facies that characterize SU2-W, and the lack of a feasible source in the area for these sediments, indicate that SU2-W represents a massive accumulation of coarse glacial proximal sediments. The thickness of SU2-W increases northward, which suggests that it is related to accumulation space, perhaps within a subglacial cavity formed by ice grounded on both sides of Whiteside Channel. We have no direct evidence of the age of SU2-W but the glacial lineations we associate with the last glacial cycle are constructed within the top of this unit. We note that the massive appearance and lack of internal reflectors indicate the accumulation of the same type of sediments either continuously or by repetition of the same sedimentary environment. In either case, the data suggest that ice stayed proximal to Punta Yartou delivering large amounts of sediment for some time.

In Central Estrecho de Magallanes near Punta Arenas (Fig. 1), there is a shallow elongated area along the axis of the strait flanked east and west by well-defined depressions, similar to what is observed in the bathymetry of southern Whiteside Channel. The area is spatially associated with limit ' $D$ ' moraines on both sides of the strait (Fig. 1), which are interpreted as recessional moraines ( 17 ka; McCulloch et al., 2005a, 2005b). Although not visible in the low-resolution bathymetry, near the southern end of the axially shallower area, Line 4 shows three outcropping or superficially buried wedge-shaped features that are interpreted as morainal banks. Their location suggests that these banks represent the submarine expression of the limit ' $D$ ' recessional features mapped on land. In this context, the two or three deeper wedge-shaped features in Line 4 (North Ramp section; Fig. 6) interpreted as morainal banks could be related with the advance of glaciers over this area during the last glacial cycle. The interpretation is that as morainal banks deposits accumulated in this area, shallowing the water depth at the calving front, it allowed the northward advance of the grounding line. This inference suggests that the thickness of the ice lobes was close to water depth during the advance phase $(\sim<300 \mathrm{~m})$ since lateral moraines are located at $<100$ masl and the successive constructions of morainal banks indicate that water depth at the ice front had to be reduced in order to allow glacier advance. We note that this deduction is consistent with what would be the expected change in ice dynamics in this area. Specifically, there is a sharp change in geometry of the strait, which is deep and narrow west of Dawson I., $\sim<60 \mathrm{~m}$ and $\sim 10 \mathrm{~km}$ respectively, but shallow and wide, $\sim<200 \mathrm{~m}$ 
and $\sim 30 \mathrm{~km}$ respectively, in the central part near Punta Arenas, which would result in widening and thinning of the glacier, reduced ice speed, and increased surface melting. Similar inferences can be made for the ice lobe flowing into Bahía Inútil (Fig. 1). It is noteworthy that the shallower morainal banks interpreted as recessional features associated with the retreat from limit ' $D$ ', occur in an area of shallow depths and low bathymetric gradient, whereas none were observed in the deeper and higher gradient central or south basins and so rapid retreat could have occurred in these areas (Fig. 8). This observation highlights the strong control that bathymetry exerted on the dynamic of glacier retreat in the region.

\section{Conclusions}

- We recognize two main types of seismic facies in the marine sedimentary section of the Magallanes Region: a) parallel reflectors with no internal complex geometries that drape underlying topography, and/or are sub-horizontal, interpreted as pelagic and/or distal glacimarine sediments; and b) high angle or sinuous reflectors, usually of high amplitude, with poor lateral continuity and associated with transparent intervals and point source diffractions, interpreted as ice proximal and/or subglacial sediments. These two dominant seismic facies are complexly arranged forming seismic units of either interglacial or glacial affinity.

- Based on the distinction and analysis of seismic units we identify two sequences of interglacial-glacial sediments representing two major glacial cycles. We interpret the youngest as representing the last glacial cycle advance and retreat, and current interglacial. Radiocarbon dating and tephrochronology results from previous studies (Kissel, 2007a, 2007b; Aracena et al., 2015), along with down section extrapolation of derived accumulation rates based on our seismic data, suggest that the pelagic sediments belonging to the youngest glacial cycle started to accumulate near the end of the Pleistocene ( 13-14 ka).

- Swath bathymetry data show glacial lineations and drumlins on the fjord/strait floor that demonstrate ice was grounded along Seno Almirantazgo, Whiteside Channel and Bahía Inútil during the last glacial cycle. Our data also suggest that recessional features are restricted to shallow and low gradient areas of the Central Estrecho de Magallanes and Bahía Inútil.

- Our data show no evidence of submerged or buried morainal banks that could constitute the marine continuation of the glacial features mapped in Dawson Island, referred as glacial limit 'E', which has been related to the Antarctic Cold Reversal (ACR) in other studies. The existence of glacial lineations, and the lack of morainal banks, advance moraines or other features associated with glacier advance in northern Whiteside Channel and western Bahía Inútil indicate that ice retreated rapidly from these areas and do not support the existence of a Late Glacial advance following deglaciation. We conclude that: a) there was no major glacial advance into the lowlands of Magallanes at the time of the ACR; b) the glacial features mapped in Dawson Island may instead correlate with the youngest moraines in Central Estrecho de Magallanes and Bahía Inútil, which correspond to glacial limit 'D' ( $\sim 17 \mathrm{ka}$ ). We propose that limit 'D' moraines represent the remains of the last deglaciation of Bahía Inútil, Whiteside Channel and Central Estrecho de Magallanes.

\section{Acknowledgments}

This research was possible thanks to the support of the National Science Foundation, Office of Polar Programs (NSF-OPP-1143843). We thank the officers, NSF representatives, crew, and scientists who sailed on the RV/IB Nathaniel B. Palmer during seismic trial cruise NBP1208 in the Magallanes Region of Chile. We thank Caroline Lavoie who processed the multibeam data. We are grateful of all the assistance of Dr. Jorge Acevedo (CEQUA) and the team of marine mammals' watchers assembled by him, Antonela Messina, Daniela Haro and Gabriela Garrido We also thank INACH and the navy office SHOA for their collaboration and the assistance provided to obtain the permit to work in Chilean territorial waters. C.R. thanks the U.S. Office of Naval Research Visiting Scientist Support grant no. N62909-13-1-V011.

\section{References}

Anderson, D.M., Archer, R.B., 1999. Preliminary evidence of early deglaciation in southern Chile. Palaeogeogr. Palaeoclimatol. Palaeoecol. 146, 295-301.

Aracena, C., Kilian, R., Lange, C.B., Bertrand, S., Lamy, F., Arz, H.W., De Pol-Holz, R., Baeza O., Pantoja, S., Kissel, C., 2015. Holocene variations in productivity associated with changes in glacier activity and freshwater flux in the central basin of the Strait of Magellan. Palaeogeogr. Palaeoclimatol. Palaeoecol. 436:112-122. http://dx.doi.org/10. 1016/j.palaeo.2015.06.023.

Bartole, R., De Muro, S., Morelli, D., Tosoratti, F., 2008. Glacigenic features and tertiary stratigraphy of the Magellan Strait (southern Chile). Geol. Acta 6 (1):85-100. http://dx doi.org/10.1344/105.000000243.

Bentley, M.J., Sugden, D.E., Hulton, N.R.J., McCulloch, R.D., 2005. The landforms and pattern of deglaciation in the Strait of Magellan and Bahía Inútil, southernmost South America. Geogr. Ann. 87A (2), 313-333.

Blunier, T., Brook, E.J., 2001. Timing of millennial-scale climate change in Antarctica and Greenland during the last glacial period. Science 291, 109-112.

Boulton, G.S., Clark, C.D., 1990. A highly mobile Laurentide ice sheet revealed by satellite images of glacial lineations. Nature $346,813-817$

Boyd, B.L., Anderson, J.B., Wellner, J.S., Fernandez, R.A., 2008. The sedimentary record of glacial retreat, Marinelli Fjord, Patagonia: regional correlations and climate ties. Mar. Geol. 255, 165-178.

Caniupan, M., Lamy, F., Lange, C.B., Kaiser, J., Arz, H., Kilian, R., Baeza Urrea, O., Aracena, C. Hebbeln, D., Kissel, C., Laj, C., Mollenhauer, G., Tiedemann, R., 2011. Millennial-scale sea surface temperature and Patagonian Ice Sheet changes off southernmost Chile $\left(53^{\circ} \mathrm{S}\right)$ over the past $\sim 60 \mathrm{kyr}$. Paleoceanography 26 , PA3221. http://dx.doi.org/10. 1029/2010PA002049.

Clapperton, C.M., 1995. The last glaciation in central Magellan Strait, southernmost Chile. Quat. Res. 44, 133-148.

Clapperton, C., 2000. Interhemispheric synchroneity of marine oxygen isotope stage 2 glacier fluctuations along the American cordilleras transect. J. Quat. Sci. 15 (4), 435-468.

Coronato, A., Salemme, M., Rabassa, J., 1999. Palaeoenvironmental conditions during the early peopling of southernmost South America (Late Glacial-Early Holocene, 148 ka B.P.). Quat. Int. 53 (54), 77-92.

Darvill, C.M., Bentley, M.J., Stokes, C.R., 2015. Geomorphology and weathering characteristics of erratic boulder trains on Tierra del Fuego, southernmost South America: implications for dating of glacial deposits. Geomorphology 228:382-397. http://dx.doi org/10.1016/j.geomorph.2014.09.017.

EPICA Community Members, 2004. Eight glacial cycles from an Antarctic ice core. Nature 429, 623-628.

Fernandez, R.A., Anderson, J.B., Wellner, J.S., Hallet, B., 2011. Timescale dependence of erosion rates, a case study: Marinelli Glacier, Cordillera Darwin, southern Patagonia. J. Geophys. Res. Earth Surf. 116. http://dx.doi.org/10.1029/2010JF001685.

García, J.L., Kaplan, M.R., Hall, B.L., Schaefer, J.M., Vega, R.M., Finkel, R., Schwartz, R., 2012 Glacier expansion in southern Patagonia throughout the Antarctic cold reversal. Geology 40, 859-862.

Garreaud, R., Lopez, P., Minvielle, M., Rojas, M., 2013. Large-scale control on the Patagonian climate. J. Clim. 26:215-230. http://dx.doi.org/10.1175/JCLI-D-12-00001.1.

Hall, B.L., Porter, C.T., Denton, G.H., Lowell, T.V., Bromley, G.R.M., 2013. Extensive recession of Cordillera Darwin glaciers in southernmost South America during Heinrich Stadial 1. Quat. Sci. Rev, 62, 49-55.

Heroy, D., Anderson, J.B., 2005. Ice sheet extend on the Antarctic Peninsula during the last glacial maximum (LGM)-insights from glacial geomorphology. Geol. Soc. Am. Bull. 117, 1497-1512.

Hulton, N.R.J., Purves, R.S., McCulloch, R.D., Sugden, D.E., Bentley, M.J., 2002. The Last Glacial Maximum and deglaciation in southern South America. Quat. Sci. Rev. 21 233-341.

Kaplan, M.R., Fogwill, C.J., Sudgen, D.E., Hulton, N.R., Kubik, P.W., Freeman, S.P., 2008. Southern Patagonian glacial chronology for the Last Glacial period and implications for southern Ocean climate. Quat. Sci. Rev. 27, 284-294.

Kilian, R., Lamy, F., 2012. A review of glacial and Holocene paleoclimate records from southernmost Patagonia (49-55º S). Quat. Sci. Rev. 53:1-23. http://dx.doi.org/10. 1016/j.quascirev.2012.07.017.

Kilian, R., Baeza, O., Steinke, T., Arevalo, M., Rios, C., Schneider, C., 2007a. Late Pleistocene to Holocene marine transgression and thermohaline control on sediment transport in the western Magallanes fjord system of Chile (53 grados S). Quat. Int 161, 90-107.

Kilian, R., Schneider, C., Koch, J., Fesq-Martin, M., Biester, H., Casassa, G., Arevalo, M., Wendt, G., Baeza, O., Behrmann, J., 2007b. Palaeoecologiacal constraints on late Glacial and Holocene ice retreat in the southern Andes (53S). Glob. Planet. Chang. 59, 49-66.

King, E.C., Hindmarsh, R.C.A., Stokes, C.R., 2009. Formation of mega-scale glacial lineations observed beneath a West Antarctic ice stream. Nat. Geosci. 2:585-588. http://dx.doi. org/10.1038/NGEO581.

Kissel, C., 2007a. The Shipboard Scientific Party. MD159-PACHIDERME-IMAGES XV. Data Report, Les rapports de campagne à la mer. Réf. OCE/2007/01. Institut Paul-Emile Victor. 
Kissel, C., 2007b. The Shipboard Scientific Party. MD159-PACHIDERME-IMAGES XV. Cruise Report, Les rapports de campagne à la mer. Réf. OCE/2007/01. Institut PaulEmile Victor.

Lagabrielle, Y., Scalabrino, B., Suárez, M., Ritz, J.F., 2010. Mio-Pliocene glaciations of Central Patagonia: new evidence and tectonics implications. Andean Geol. 37 (2), 276-299.

Lamy, F., Kilian, R., Helge Arz, H.W., Francois, J.P., Kaiser, J., Prange, M., Steinke, T., 2010 Holocene changes in the position and intensity of the southern westerly wind belt. Nat. Geosci. 3:695-699. http://dx.doi.org/10.1038/NGE0959.

Mansilla, C.A., McCulloch, R.D., Morello, F., 2016. Palaeoenvironmental change in southern Patagonia during the Lateglacial and Holocene: implications for forest refugia and climate reconstructions. Palaeogeogr. Palaeoclimatol. Palaeoecol. 447:1-11. http://dx. doi.org/10.1016/j.palaeo.2016.01.041.

Markgraf, V., Huber, U.M., 2010. Late and postglacial vegetation and fire history in southern Patagonia and Tierra del Fuego. Palaeogeogr. Palaeoclimatol. Palaeoecol. 297, 351-366.

McCulloch, R.D., Bentley, M.J., 1998. Late glacial ice advances in the Strait of Magellan, southern Chile. Quat. Sci. Rev. 17, 775-787.

McCulloch, R.D., Davies, S.J., 2001. Late-glacial and Holocene palaeoenvironmental change in the central Strait of Magellan, southern Patagonia. Palaeogeogr. Palaeoclimatol. Palaeoecol. 173, 143-173.

McCulloch, R.D., Bentley, M.J., Purves, R.S., Hulton, N.R.J., Sugden, D.E., Clapperton, C.M. 2000. Climatic inferences from glacial and palaeoecological evidence at the last glacia termination, southern South America. J. Quat. Sci. 15 (4), 409-417.

McCulloch, R.D., Fogwill, C.J., Sugden, D.E., Bentley, M.J., Kubik, P.W., 2005a. Chronology of the last glaciation in central Strait of Magellan and Bahía Inútil, southernmost South America. Geogr. Ann. 87A (2), 289-312.

McCulloch, R.D., Bentley, M.J., Tipping, R.M., Clapperton, C.M., 2005b. Evidence for lateglacial ice dammed lakes in the central Strait of Magellan and Bahía Inútil, southernmost South America. Geogr. Ann. 87A (2), 335-362.

Meier, M.F., Post, A., 1987. Fast tidewater glaciers. J. Geophys. Res. Solid Earth Planets 92, 9051-9058.

Moreno, P.I., Kaplan, M.R., François, J.P., Villa-Martinez, R., Moy, C.M., Stern, C.R., Kubik, P.W., 2009. Renewed glacial activity during the Antarctic cold reversal and persistence of cold conditions until $11.5 \mathrm{ka}$ in southwestern Patagonia. Geology 37, 375-378.
O'Cofaigh, C., Dowdeswell, J.A., Allen, C.S., Hiemstrac, J.F., Pudseyb, C.F., Evans, J., Evans, D.J.A., 2005. Flow dynamics and till genesis associated with a marine-based Antarctic palaeo-ice stream. Quat. Sci. Rev. 24, 709-740.

Pedro, J.B., Van Ommen, T.D., Rasmussen, S.O., Morgan, V.I., Chappellaz, J., Moy, A.D., Masson-Delmotte, V., Delmotte, M., 2011. The last deglaciation: timing the bipolar seesaw. Clim. Past 7:671-683. http://dx.doi.org/10.5194/cp-7-671-2011.

Powell, R.D., 1984. Glacimarine processes and inductive lithofacies modelling of ice shelf and tidewater glacier sediments based on Quaternary examples. Mar. Geol. 57, 1-52.

Powell, R.D., Molnia, B.F., 1989. Glacimarine sedimentary processes, facies and morphology of the south-southeast Alaska shelf and fjords. Mar. Geol. 85, 359-390.

Post, A., 1975. Preliminary hydrography and historical terminal changes of Columbia Glacier. Hydrologic Atlas. United States Geological Survey Numbered Series (HA-559, 3 sheets).

Rabassa, J., Coronato, A., Bujalesky, G., Salemme, M., Roig, C., Meglioli, A., Heusser, C., Gordillo, S., Roig, F., Borromei, A., Quattrocchio, M., 2000. Quaternary of Tierra del Fuego, southernmost South America: and updated review. Quat. Int. 68-71, 217-240.

Rabassa, J., Coronato, A., Salemme, M., 2005. Chronology of the late Cenozoic Patagonian glaciations and their correlation with biostratigraphic units of the Pampean region (Argentina). J. S. Am. Earth Sci. 20, 81-103.

SERNAGEOMIN, 2003. Mapa Geológico de Chile: versión digital. Servicio Nacional de Geología y Minería, Publicación Geológica Digital. 4 ((CD-ROM, versión1.0, 2003). Santiago).

Stravers, J.A., Powell, R.D., 1997. Glacial debris flow deposits on the Baffin Island shelf: seismic facies architecture of till-tongue-like deposits. Mar. Geol. 143, 151-168.

Sugden, D.E., Bentley, M.J., Fogwill, C.J., Hulton, N.J.R., McCulloch, R.D., Purves, R.S., 2005. Late-glacial glacier events in southernmost South America: a blend of 'northern' and 'southern' hemispheric climate signals? Geogr. Ann. 87A (2), 273-288.

Syvitski, J.P.M., 1989. On the deposition of sediment within glacier-influenced fjords: oceanographic controls. Mar. Geol. 85, 301-329.

Wellner, J.S., Heroy, D.C., Anderson, J.B., 2006. The death mask of the Antarctic ice sheet: comparison of glacial geomorphic features across the continental shelf. Geomorphology $75,157-171$.

Wenzens, G., 2006. Terminal Moraines, Outwash Plains, and Lake Terraces in the vicinity of Lago Cardiel (498S; Patagonia, Argentina) - evidence for Miocene Andean foreland glaciations. Arct. Antarct. Alp. Res. 38 (2), 276-291. 